Şen, Ü. (2020). Millî Eğitim Bakanlığının yurt dışına Türkçe ve Türk kültürü dersi öğretmeni görevlendirme politikasının yıllara göre değerlendirilmesi. Ana Dili Eğitimi Dergisi, 8 (1), 217-236.

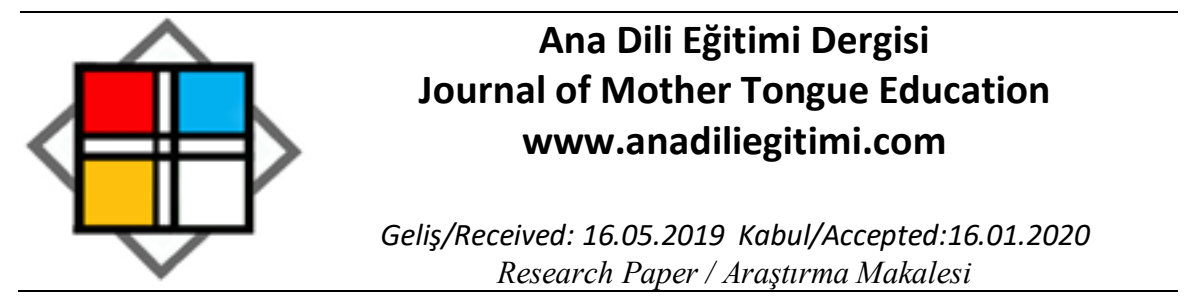

\title{
Millî Eğitim Bakanlığının Yurt Dışına Türkçe ve Türk Kültürü Dersi Öğretmeni Görevlendirme Politikasının Yıllara Göre Değerlendirilmesi *
}

Ülker ŞEN**

Öz

Yurt dışında yaşayan Türk vatandaşlarının çocuklarının ana dillerini yaşatmaları, kültürlerinden kopmamaları için Millî Eğitim Bakanlığı her yıl öğretmen görevlendirmesi yapmaktadır. Millî Eğitim Bakanlı̆̆ı ilk kez 1965 'te Almanya'ya 17 öğretmen ile başlattığı bu politikasını günümüze kadar devam ettirmiştir. Son yıllarda ortalama 400 öğretmen Bakanlıkça görevlendirilmektedir. Yurt dışında görev yapacak öğretmenlerin aldıkları sorumluluğun önemi nispetinde seçimlerinin de titizlikle yapılması gerekmektedir. Çalışma bu önemden yola çıkılarak oluşturulmuştur. Çalışmada "Geçmişten günümüze Millî Eğitim Bakanlığı yurt dışı teşkilatlarında görevlendirilecek öğretmenlerin seçiminde nasıl bir politika izlemiştir, bu politika yıllara göre değişim göstermekte midir?" sorularına yanıt aranmıştır. Nitel araştırma kapsamında yapılan çalışmanın verileri doküman incelemesi yöntemiyle elde edilmiştir. Çalışma kapsamında ulaşılan verilerin analizinde betimsel analiz kullanılmıştır. Çalışma, Millî Eğitim Bakanlığının yurt dışı teşkilatlarında öğretmen görevlendirmesi yaptığı 2010-2019 yılları ile sınırlı tutulmuştur. Araştırma sonucunda ön plana çıkan sonuçlar arasında seçilecek öğretmenlerin branşlarında bir standardın olmadığı, her sene farklı branşlardan öğretmenlerin görevlendirildiği görülmüştür.

Anahtar Kelimeler: Türkçe ve Türk kültürü öğretmeni, öğretmen yetiştirme, yurt dışındaki Türk çocuklarına Türkçe öğretimi, Türkçe ve Türk kültürü dersi, Millî Eğitim Bakanlığı

\section{Evaluation of Turkish and Turkish Culture Teacher Assigment Policy of The Ministry of National Education by Periods}

\begin{abstract}
The Ministry of National Education has maintained this policy for the first time in 1965 with 17 teachers in Germany until 2019. In recent years an average 400 teachers have been assigned by Ministry. Teachers who will be working abroad need to be meticulous about their responsibilities as well as their choices. The study was formed from this importance. "What kind of policy has the Ministry of National Education pursued in the selection of the teachers to be appointed in the foreign organizations from past to present, does this policy change according to years?" The answers has been searched in these study. The study is descriptive research. The data of the study were obtained through a document review. Descriptive analysis was used in the analysis of the data obtained within the scope of the study. The study area was limited to between 2010-2019 years when the Ministry of National Education appointed teachers in the foreign organizations. Among the important results of the study, it was seen that there was no standard in the branches of the teachers to be chosen and teachers from different branches were assigned each year.

Keywords: Turkish and Turkish culture teacher, teacher training, Turkish children abroad, Turkish and Turkish culture course, Ministry of National Education

\footnotetext{
* Çalışma, 17-19 Ekim 2018 tarihlerinde düzenlenen X. Dünya Dili Türkçe Sempozyumu'nda sunulan sözlü bildirinin genişletilmiş hâlidir.

${ }^{* *}$ Doç. Dr., Gazi Üniversitesi, Gazi Eğitim Fakültesi, Türkçe ve Sosyal Alanlar Eğitimi Bölüm, Ankara, ulkersen@gazi.edu.tr, ORCID: orcid.org/ 0000-0002-1855-6336
} 


\section{Giriş}

Türkiye Cumhuriyeti Devleti, vatandaşlarının her birinin eğitim öğretim ile ilgili haklarını başta Anayasa ve 1739 sayılı Millî Eğitim Temel Kanunu olmak üzere kanunlarla koruma altına almıştır. Millî Eğitim Bakanlığı da Devlet bünyesinde Anayasa, 430 sayılı Tevhidi Tedrisat Kanunu, 1739 sayılı Millî Eğitim Temel Kanunu ile kalkınma plan ve programları doğrultusunda millî eğitim hizmetlerini yürütmek üzere kurulmuştur (25/8/2011 tarihli ve 652 sayılı Millî Eğitim Bakanlığının Teşkilat ve Görevleri Hakkında Kanun Hükmünde Kararname bk. Resmî Gazete, S. 28054). Millî Eğitim Bakanlığının eğitim hizmetlerinin en önemli parçasını öğretmenler oluşturmaktadır. Öğretmenlerin atama ve görevlendirme işlemleri (Bakanlığa bağlı kurumlar için) Bakanlıkça yapılmaktadır. Daha önce de ifade edildiği gibi devlet her bir vatandaşına eğitim öğretim hizmetlerini sunmakla yükümlüdür ancak bu durum sadece Türkiye sınırları için geçerli değildir. Dünyanın dört bir yanında farklı ülkelerde farklı sebeplerle yaşayan milyonlarca Türk vatandaşı da bulunmaktadır. Millî Eğitim Bakanlığı yurt dışında yaşayan Türk vatandaşlarının Türkçeden ve Türk kültüründen kopmamaları, Türkiye ile olan bağlarının devam etmesi için öğretmen görevlendirmesi yapmaktadır. Görevlendirilen öğretmenler vasıtası ile "Türk kültürünün yurt dışında tanıtılması, yayılması ve korunması, yurt dışındaki vatandaşların ve soydaşların kültürel bağlarının korunması, güçlendirilmesi ve dinî konularda aydınlatılması ile Türk dilinin öğretilmesi" amaçlanmıştır (Resmî Gazete S. 25157). Yurt dışına görevlendirilecek öğretmenlerin seçimi, misyonları gereği çok önemlidir. Yurt dışında yaşayan Türk çocuklarına Türkçe ve Türk Kültürü dersi vermek üzere görevlendirilen öğretmenlerle ilgili yapılan çalışmalarda daha çok öğretmenlerin derslerde karşılaştıkları sorunların ve derslere yönelik görüşlerinin ele alındığı görülmüştür (Şen ve Burgul Adıgüzel, 2018, 70). Yapılan bu çalışma Millî Eğitim Bakanlığının yurt dışı teşkilatlarında öğretmen görevlendirme politikasını ortaya koyması, Türkiye'de iki dilli Türk çocuklarına Türkçe öğretmeni yetiştirme programının oluşturulmasına katkı sağlaması, alanda araştırma yapanlara veri kaynağı oluşturması açısından önemlidir.

Yukarıda ifade edilen bilgilerden hareketle bu çalışmanın problem cümlesi "Geçmişten günümüze Millî Eğitim Bakanlığı (MEB) yurt dışı teşkilatlarında görevlendirilecek öğretmenlerin seçiminde nasıl bir politika izlemiştir, bu politika yıllara göre değişim göstermekte midir?" şeklinde oluşturulmuştur. Alt problem cümleleri ise aşağıdadır:

1. Millî Eğitim Bakanlığınca yurt dışı teşkilatlarında görevlendirilecek öğretmenlerin seçimine ilişkin oluşturulan başvuru şartlarında yıllara göre bir değişim gözlenmekte midir?

2. Millî Eğitim Bakanlığınca yurt dışı teşkilatlarında görevlendirilecek öğretmenlerin seçimine ilişkin atanmaya esas olan alanlar ve öğretmen sayılarında yıllara göre bir değişim gözlenmekte midir?

3. Millî Eğitim Bakanlığınca yurt dışı teşkilatlarında görevlendirilecek öğretmenlerin seçimine ilişkin yapılan sınavların içeriğinde ve yapılan sınavlarda yıllara göre bir değişim gözlenmekte midir?

4. Millî Eğitim Bakanlığınca yurt dışı teşkilatlarında görevlendirilecek öğretmenlerin seçimine ilişkin uygulanan uyum seminerlerinin uygulanmasında yıllara göre bir değişim gözlenmekte midir?

\section{Araştırmanın Modeli}

\section{Yöntem}

Çalışma nitel araştırma özelliğindedir. Nitel araştırma, gözlem, görüşme ve doküman analizi gibi nitel veri toplama yöntemlerinin kullanıldığı, algıların ve olayların doğal ortamda, gerçekçi ve bütüncül bir biçimde ortaya konmasına yönelik, nitel bir sürecin izlendiği araştırma olarak tanımlanabilir (Yıldırım ve Şimşek, 2008, 14). Bu çalışmada nitel araştırmanın veri toplama yöntemlerinden doküman analizi yöntemi benimsenmiştir. Doküman incelemesi veya analizi, tek başına bir araştırma yöntemi olabildiği gibi, diğer nitel yöntemlerin (görüşme veya gözlem) kullanıldığı durumlarda da ek bilgi kaynağı olarak kullanılabilmektedir (Yıldııım ve Şimşek, 2008, 140).

\section{Araştırma Grubu}

Araştırmanın çalışma nesnelerini Millî Eğitim Bakanlığının yurt dışında görevlendirilecek öğretmelerin başvuru şartlarını, sınav içeriklerini belirlediği "başvuru kılavuzları" oluşturmaktadır. Değerlendirmeye alınan bu başvuru kılavuzları, 2010-2019 yılları arasında MEB tarafından yayımlanan 
Millî Eğitim Bakanlığının Yurt Dışına Türkçe ve Türk Kültürü Dersi Öğretmeni Görevlendirme Politikasının Yıllara Göre Değerlendirilmesi

Yurt Dışında Görevlendirilecek Öğretmenlerin Mesleki Yeterlilik Sınavı ve Temsil Yeteneği Mülakatı Başvuru Kılavuzlarıdır. 2010 öncesinde yayımlanmış bir kılavuza rastlanmamıştır.

\section{Veri Toplama Araçları}

Çalışmaya ait verilerin toplanmasında "başvuru şartları, atanmaya esas olan alanlar ve öğretmen sayıları, yapılan sınavlar, uyum semineri" ölçütlerinden oluşan bir liste kullanılmıştır. Belirlenen bu ölçütler çerçevesinde kılavuzlar incelenmiş ve karşılaştırmalı bir değerlendirme yapılmıştır.

\section{Verilerin Toplanması}

Çalışmanın verileri doküman taraması yoluyla elde edilmiştir. Doküman taraması yolu ile verilerin toplanmasında birinci aşama veri kaynağının elde edilmesi, ikinci aşama kaynağın okunması, üçüncü aşama not alma ve son aşamayı değerlendirme oluşturmaktadır. Bu çalışmada da doküman taraması ile veri toplamanın aşamalarına uygun hareket edilmiştir. Birinci aşamada veri kaynağını oluşturan Yurt Dışında Görevlendirilecek Öğretmenlerin Mesleki Yeterlilik Sınavı ve Temsil Yeteneği Mülakatı Başvuru Kılavuzları temin edilmiş, kılavuzlar okunmuş, çalışmanın amaçları doğrultusunda kılavuzların içeriğine ilişkin notlar alınmış, son aşamada notların değerlendirilmesi gerçekleştirilmiştir.

\section{Verilerin Analizi}

Çalışma kapsamında ulaşılan veriler betimsel analizle değerlendirilmiştir. Betimsel analiz, çeşitli veri toplama teknikleri ile elde edilmiş verilerin daha önceden belirlenmiş temalara göre özetlenmesi ve yorumlanmasını içeren bir nitel veri analiz türüdür. Bu analiz türünde araştırmacı görüştüğü ya da gözlemiş olduğu bireylerin görüşlerini çarpıcı bir biçimde yansıtabilmek amacıyla doğrudan alıntılara sık sık yer verebilmektedir. Bu analiz türünde temel amaç, elde edilmiş olan bulguların okuyucuya özetlenmiş ve yorumlanmış bir biçimde sunulmasıdır (Yıldırım ve Şimşek, 2008).

Betimsel analiz dört aşamadan oluşur: 1. Betimsel Analiz İçin Bir Çerçeve Oluşturma, 2. Tematik Çerçeveye Göre Verilerin İşlenmesi, 3. Bulguların Tanımlanması, 4. Bulguların Yorumlanması (Şimşek, 2009). Bu çalışmada betimsel analizin aşamalarına uygun olarak:

1. Betimsel Analiz İçin Bir Çerçeve Oluşturma: Araştırmanın kavramsal çerçevesinden ve veri kaynaklarının niteliğinden yola çıkılarak verilerin "başvuru şartları, atanmaya esas olan alanlar ve öğretmen sayıları, yapılan sınavlar, uyum semineri" temaları altında organize edilmesine karar verilmiştir.

2. Tematik Çerçeveye Göre Verilerin İşlenmesi: "Başvuru şartları, atanmaya esas olan alanlar ve öğretmen sayıları, yapılan sınavlar, uyum semineri" şeklinde ifade edilen tematik çerçeveye göre, elde edilen veriler okunmuş, düzenlenmiştir.

3. Bulguların Tanımlanması: Düzenlenmiş ve bir araya getirilmiş verilerin tanımları, özellikleri verilmiştir.

4. Bulguların Yorumlanması: Elde edilen bulgular birbirleriyle karşılaştırmalı olarak yorumlanmıştır.

\section{Geçerlik ve Güvenirlik}

Bilimsel çalışmalarda elde edilen sonuçların inandırıcılığı önemli bir ölçüttür. Nicel çalışmalarda geçerlik ve güvenirlik olarak karşımıza çıkan bu ölçüt nitel araştırmalarda yerini inanııırık, sonuçların doğruluğu ve araştırmacının yetkinliği gibi kavramlara bırakır. Bu bağlamda nitel araştırma niteliğinde olan bu çalışmada inandırıcılık

1. Araştırmacı yetkinliği,

2. Literatüre ve veri kaynağının niteliğine bağlı olarak kategorilerin/temaların belirlenmesi,

3. Temaların belirlenmesi sürecinde uzman görüşüne başvurulması,

4. Verilerin toplanma süreci ve analizindeki işlemlerin ayrıntılı olarak verilmesi,

5. Veri kaynağını oluşturan başvuru kılavuzlarına erişimin sanal ortamda bütün araştırmacılara açık olması ve çalışma verilerin / sonuçların teyit edilebilirliği, 
6. Nitelikli veri kaynağı kullanııması (Millı̂ Eğitim Bakanlığı tarafından basımı yapılan resmî belge niteliğinde olması) ile sağlanmıştır.

\section{Başvuru Şartlarına iliş̧kin Bulgular}

\section{Bulgular}

Tablo 1.

2010-2019 Yılları Başvuru Şartları

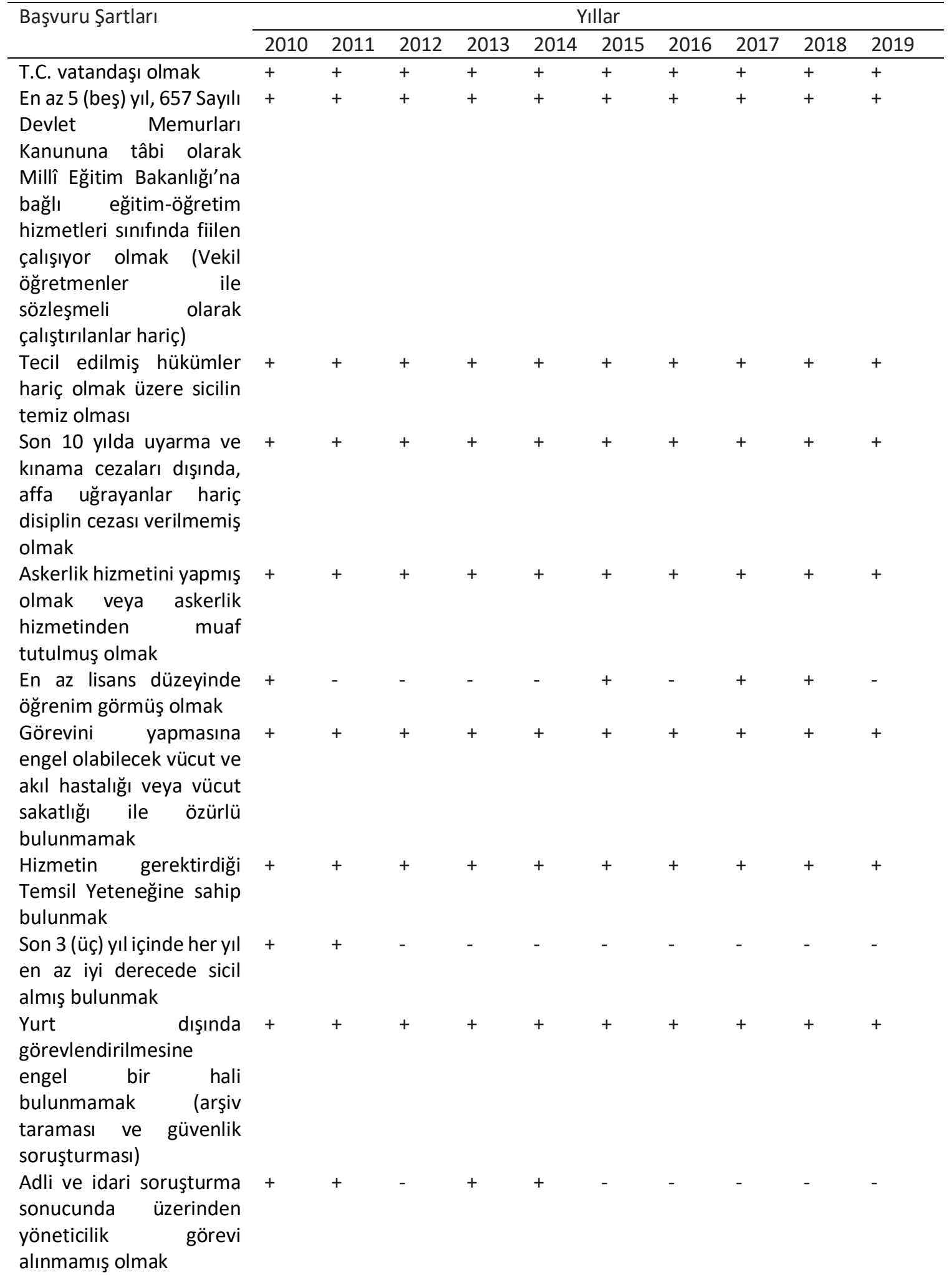


Millî Eğitim Bakanlığının Yurt Dışına Türkçe ve Türk Kültürü Dersi Öğretmeni Görevlendirme Politikasının Yıllara Göre Değerlendirilmesi

Tablo 1 .

2010-2019 Yılları Başvuru Şartları (Devamı)

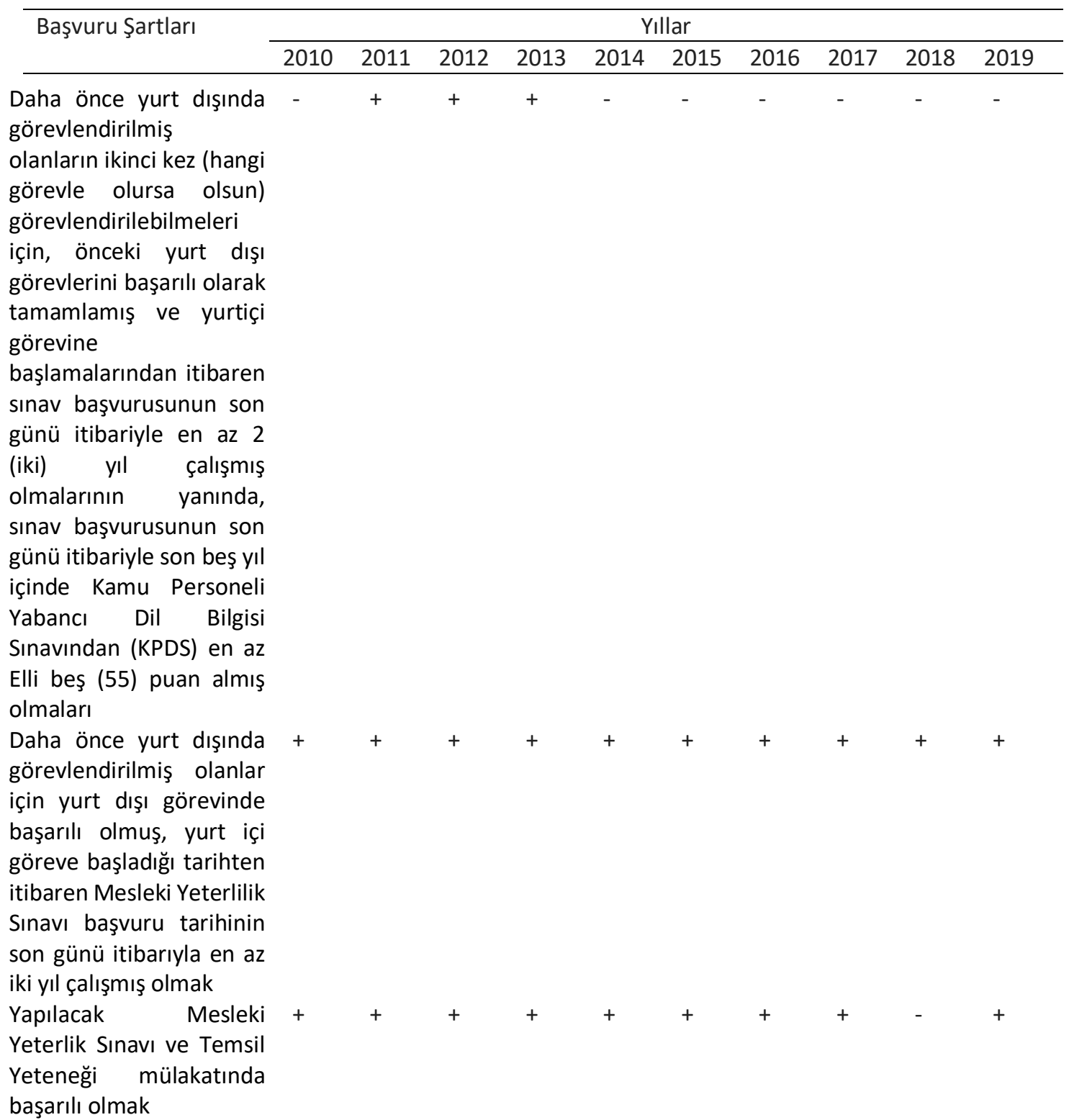

Tablo 1 incelendiğinde son dokuz yıldır yurt dışı teşkilatlarında görevlendirilecek öğretmenlerin seçiminde başvuru şartlarında köklü bir değişikliğe gidilmediği görülmektedir. Farklılığın olduğu şartlar şunlardır: "En az lisans düzeyinde öğrenim görmüş olmak", "Son 3 (üç) yıl içinde her yıl en az iyi derecede sicil almış bulunmak", "Adli ve idari soruşturma sonucunda üzerinden yöneticilik görevi alınmamış olmak" ve "yurt dışına ikinci kez görevlendirmelerde dil puanın (55 puan) aranması". Bu değişikliklerden hareketle Bakanlığın 2011-12-13-14 ve 2016 yıllarında ön lisans mezunu öğretmen atama politikasının son iki yıldır işlevini yitirdiği söylenebilir. Son beş yıldır başvurularda öğretmenlerin adli ve idari soruşturma sonucunda üzerinden yöneticilik görevinin alınıp alınmadığı dikkate alınmamaktadır. Yine son beş yıldır daha önce yurt dışında görevlendirilmiş olanların ikinci kez görevlendirmelerinde önceki görevi başarılı bir şekilde tamamlama şartı yanında istenen 55 yabancı dil puanının istenmediği görülmektedir. Genel bir değerlendirme yapıldığında yurt dışına Türkçe ve Türk Kültürü dersi öğretmeni olarak görevlendirilecek öğretmenler için Bakanlığın sınırlayıcl, eleyici bir politika izlemediği söylenebilir. 


\section{Atanmaya Esas Olan Alanlar ve Öğretmen Sayılarına ilişkin Bulgular}

MEB her yıl ülkelerin talep durumuna, ihtiyacına göre belli sayıda Türkçe ve Türk Kültürü dersi öğretmeni görevlendirmesi yapmaktadır. 2010-2019 yılları arasında yurt dışına Türkçe ve Türk Kültürü dersi öğretmeni olarak görevlendirilecek öğretmenlerin branşları ve seçilecek öğretmenlerin sayılarına aşağıdaki tablolarda sunulmuştur.

Tablo 2 .

2010 Yılı Türkçe ve Türk Kültürü Dersi Öğretmeni Olarak Atanmaya Esas Olan Alanlar ve Öğretmen Sayıları

\begin{tabular}{|c|c|c|}
\hline Atanmasına Esas Olan Alan & $\begin{array}{l}\text { Yabancı } \\
\text { Dili }\end{array}$ & Seçilecek Öğretmen Sayısı \\
\hline $\begin{array}{l}\text { Türkçe, Almanca, Sınıf Öğretmeni (Almanca } \\
\text { Konuşulan Ülkeler) }\end{array}$ & Almanca & 75 \\
\hline $\begin{array}{l}\text { Beden Eğitimi Öğretmeni;(Resmî Kurumlardan } \\
\text { alınmış Halk Oyunları Usta Öğreticilik Belgesi } \\
\text { Olanlar) Müzik Öğretmeni; Devlet Türk Müziği } \\
\text { Konservatuvarı Halk Oyunları Bölümü Mezunu) } \\
\text { (Almanca Konuşulan Ülkeler) }\end{array}$ & Almanca & 3 \\
\hline $\begin{array}{l}\text { Okulöncesi Öğretmenliği (Almanca Konuşulan } \\
\text { Ülkeler) }\end{array}$ & Almanca & 2 \\
\hline Rehber Öğretmen (Almanca Konuşulan Ülkeler) & Almanca & 5 \\
\hline $\begin{array}{l}\text { Türkçe, Fransızca, Sınıf Öğretmeni (Fransızca } \\
\text { Konuşulan Ülkeler) }\end{array}$ & Fransızca & 75 \\
\hline $\begin{array}{l}\text { Rehberlik Öğretmeni (Fransızca Konuşulan } \\
\text { Ülkeler) }\end{array}$ & Fransızca & 3 \\
\hline $\begin{array}{l}\text { Beden Eğitimi Öğretmeni ;(Resmî Kurumlardan } \\
\text { alınmış Halk Oyunları Usta Öğreticilik Belgesi } \\
\text { Olanlar) Müzik Öğretmeni; Devlet Türk Müziği } \\
\text { Konservatuvarı Halk Oyunları Bölümü Mezunu) } \\
\text { (Fransızca Konuşulan Ülkeler) }\end{array}$ & Fransızca & 3 \\
\hline Türkçe (İngilizce Konuşulan ülkeler) & İngilizce & 6 \\
\hline Sınıf Öğretmeni (İngilizce Konuşulan ülkeler) & İngilizce & 8 \\
\hline Rehber Öğretmen (İngilizce Konuşulan ülkeler) & İngilizce & 2 \\
\hline TOPLAM & & 182 \\
\hline
\end{tabular}

Tablo 2'ye bakıldığında 2010 yılında Türkçe ve Türk Kültürü dersini vermek üzere görevlendirilecek öğretmenlerin branşlarının "Türkçe, Almanca, sınıf, beden eğitimi, müzik, okul öncesi, Fransızca, rehberlik öğretmeni" şeklinde sıralandığı; en çok görevlendirmenin Almanca konuşulan ülkelere yapıldığı görülmektedir. Toplamda 2010 yılında yurt dışına Türkçe ve Türk Kültürü dersi öğretmeni olarak 182 görevlendirme yapılmıştır.

Tablo 3.

2011 Yılı Türkçe ve Türk Kültürü Dersi Öğretmeni Olarak Atanmaya Esas Olan Alanlar ve Öğretmen Sayıları

\begin{tabular}{lcc}
\hline Atanmasına Esas Olan Alan & Yabancı Dili & Seçilecek Öğretmen Sayısı \\
\hline Türkçe, Türk Dili ve Edebiyatı, Sosyal Bilgiler, Tarih, & & 100 \\
$\begin{array}{l}\text { Din Kültürü ve Ahlak Bilgisi, Almanca, Sınıf } \\
\text { Öğretmeni (Almanca Konuşulan Ülkeler- Almanya, }\end{array}$ & Almanca & \\
$\begin{array}{l}\text { İsviçre) } \\
\text { Rehber Öğretmen }\end{array}$ & Almanca & 4 \\
\hline
\end{tabular}


Millî Eğitim Bakanlığının Yurt Dışına Türkçe ve Türk Kültürü Dersi Öğretmeni Görevlendirme Politikasının Yıllara Göre Değerlendirilmesi

Tablo 3.

2011 Yılı Türkçe ve Türk Kültürü Dersi Öğretmeni Olarak Atanmaya Esas Olan Alanlar ve Öğretmen Sayıları (Devamı)

\begin{tabular}{lcc}
\hline Atanmasına Esas Olan Alan & Yabancı Dili & Seçilecek Öğretmen Sayısı \\
\hline $\begin{array}{l}\text { Okulöncesi Öğretmeni (Bayan) } \\
\text { Türkçe, Türk Dili ve Edebiyatı, Sosyal Bilgiler, Tarih, }\end{array}$ & Almanca & 6 \\
$\begin{array}{l}\text { Din Kültürü ve Ahlak Bilgisi, Fransızca, Sınıf } \\
\text { Öğretmeni (Fransızca Konuşulan Ülkeler- Fransa, }\end{array}$ & Fransızca & 80 \\
$\begin{array}{l}\text { Belçika, İsviçre, Lüksemburg) } \\
\text { Rehber Öğretmen }\end{array}$ & & \\
$\begin{array}{l}\text { Okulöncesi Öğretmeni (Bayan) } \\
\text { Türkçe, Türk Dili ve Edebiyatı, Sosyal Bilgiler, Tarih, }\end{array}$ & Fransızca & 4 \\
$\begin{array}{l}\text { Din Kültürü ve Ahlak Bilgisi, İngilizce, Sınıf } \\
\text { Öğretmeni (Ingilizce Konuşulan ülkeler- İngiltere, }\end{array}$ & Ingilizce & 6 \\
Belçika, İtalya) & & 10 \\
\hline TOPLAM & & \\
\hline
\end{tabular}

2011 yılında Türkçe ve Türk Kültürü dersi öğretmeni olarak atanacakların atanmaya esas olan alanları; Türkçe, Türk dili ve edebiyatı, sosyal bilgiler, tarih, din kültürü ve ahlak bilgisi, Almanca, Fransızca, okulöncesi, İngilizce, sınıf öğretmeni ve rehber öğretmen şeklinde sıralanmaktadır. 2011 yılında Türk dili ve edebiyatı, sosyal bilgiler, tarih, din kültürü ve ahlak bilgisi, İngilizce öğretmenleri de atamaya esas olan alanlar olarak ilk kez listeye girmiş, beden eğitimi ve müzik öğretmeleri listeden çıkarılmıştır. 2011 yılında toplamda 210 Türkçe ve Türk Kültürü dersi öğretmeni görevlendirmesi yapılmıştır. Görevlendirmelerde yine Almanca konuşan ülkeler (110 öğretmen) ön plandadır.

Tablo 4.

2012 Yılı Türkçe ve Türk Kültürü Dersi Öğretmeni Olarak Atanmaya Esas Olan Alanlar ve Öğretmen Sayıları

\begin{tabular}{|c|c|c|}
\hline Atanmasına Esas Olan Alan & Yabancı Dili & Seçilecek Öğretmen Sayıs \\
\hline $\begin{array}{l}\text { Türkçe, Türk Dili ve Edebiyatı, Almanca, İngilizce, } \\
\text { Fransızca, Sınıf Öğretmeni, Din Kültürü ve Ahlak } \\
\text { Bilgisi, Sosyal Bilgiler }\end{array}$ & Almanca & 120 \\
\hline Rehber Öğretmen & Almanca & 4 \\
\hline Okulöncesi Öğretmeni (Bayan) & Almanca & 4 \\
\hline $\begin{array}{l}\text { Türkçe, Türk Dili ve Edebiyatı, Fransızca, } \\
\text { İngilizce, Almanca, Sınıf Öğretmeni, Din Kültürü } \\
\text { ve Ahlak Bilgisi, Sosyal Bilgiler }\end{array}$ & Fransızca & 80 \\
\hline Rehber Öğretmen & Fransizca & 4 \\
\hline Okulöncesi Öğretmeni (Bayan) & Fransızca & 6 \\
\hline $\begin{array}{l}\text { Türkçe, Türk Dili ve Edebiyatı, İngilizce, Almanca, } \\
\text { Fransızca, Sınıf Öğretmeni, Din Kültürü ve Ahlak } \\
\text { Bilgisi, Sosyal Bilgiler }\end{array}$ & İngilizce & 15 \\
\hline Okulöncesi Öğretmenliği (Bayan) & İngilizce & 2 \\
\hline $\begin{array}{l}\text { Türkçe, Türk Dili ve Edebiyatı, Fransızca, Sınıf } \\
\text { Öğretmeni, Din Kültürü ve Ahlak Bilgisi, Sosyal } \\
\text { Bilgiler }\end{array}$ & İtalyanca & 3 \\
\hline TOPLAM & & 238 \\
\hline
\end{tabular}

2012 yılında Türkçe, Türk dili ve edebiyatı, sosyal bilgiler, din kültürü ve ahlak bilgisi, Almanca, Fransızca, okulöncesi, İngilizce, sınıf öğretmeni ve rehber öğretmen yine atanmaya esas olan 
alanlardandır. Bir önceki yıldan farklı olarak "tarih öğretmeni" listeden çıkarılmıştır. 2012 yılında toplamda 238 Türkçe ve Türk Kültürü dersi öğretmeni görevlendirmesi yapılmıştır. 2012 yılında ilk kez İtalyanca konuşan ülkeler için öğretmen kontenjanı açılmıştır. Burada ilginç olan ülkelerde konuşulan yabancı dile göre Almanca, Fransızca, İngilizce öğretmenleri kendilerine listede yer bulabilirken İtalyanca öğretmenlerinin listede yer almamasıdır.

Tablo 5.

2013 Yılı Türkçe ve Türk Kültürü Dersi Öğretmeni Olarak Atanmaya Esas Olan Alanlar ve Öğretmen Sayıları

\begin{tabular}{lcc}
\hline \multicolumn{1}{c}{ Atanmasına Esas Olan Alan } & Yabancı Dili & Seçilecek Öğretmen Sayısı \\
\hline Türkçe, Türk Dili ve Edebiyatı, Almanca, Sınıf & Almanca & 120 \\
Öğretmeni, Din Kültürü ve Ahlak Bilgisi, Sosyal & & \\
Bilgiler & & 2 \\
Özel Eğitim Öğretmeni (İşitme Engelliler) & Almanca & 60 \\
$\begin{array}{l}\text { Türkçe, Türk Dili ve Edebiyatı, Fransızca, Sınıf } \\
\text { Öğretmeni, Din Kültürü ve Ahlak Bilgisi, Sosyal }\end{array}$ & Fransızca & \\
Bilgiler & & 4 \\
Rehber Öğretmen & Fransızca & 60 \\
Türkçe, Türk Dili ve Edebiyatı, İngilizce, Sınıf & İngilizce & \\
öğretmeni, Din Kültürü ve Ahlak Bilgisi, Sosyal & & 2 \\
Bilgiler & & 248 \\
Okul Öncesi Öğretmeni (Bayan) & Ingilizce & \\
\hline TOPLAM & & \\
\hline
\end{tabular}

2013 yılında Türkçe ve Türk Kültürü dersi vermek üzere Türkçe, Türk dili ve edebiyatı, İngilizce, Fransızca, Almanca, sınıf, din kültürü ve ahlak bilgisi, sosyal bilgiler, okul öncesi öğretmeni, rehber öğretmen" branşlarında atamalar yapılmıştır. 2013 yılında ilk kez özel eğitim öğretmenlerinin görevlendirmesi de yapılmıştır. Toplamda 2013 yılında 248 öğretmenin yurt dışına görevlendirmesi yapılmıştır.

Tablo 6.

2014 Yılı Türkçe ve Türk Kültürü Dersi Öğretmeni Olarak Atanmaya Esas Olan Alanlar ve Öğretmen Sayıları

\begin{tabular}{|c|c|c|}
\hline Atanmasına Esas Olan Alan & $\begin{array}{l}\text { Yabancı } \\
\text { Dili }\end{array}$ & Seçilecek Öğretmen Sayısı \\
\hline $\begin{array}{l}\text { Türkçe, Türk Dili ve Edebiyatı, Almanca, Sınıf } \\
\text { Öğretmeni, Din Kültürü ve Ahlak Bilgisi, İmam Hatip } \\
\text { Meslek Dersleri (i.H.L), Sosyal Bilgiler }\end{array}$ & Almanca & 150 \\
\hline Okul Öncesi öğretmeni & Almanca & 3 \\
\hline Rehberlik (Rehber Öğretmeni.) & Almanca & 4 \\
\hline $\begin{array}{l}\text { Türkçe, Türk Dili ve Edebiyatı, Fransızca, Sınıf } \\
\text { Öğretmeni, Din Kültürü ve Ahlak Bilgisi, İmam Hatip } \\
\text { Meslek Dersleri (ïLL), Sosyal Bilgiler Öğretmeni }\end{array}$ & Fransızca & 64 \\
\hline Rehberlik (Rehber Öğretmeni.) & Fransızca & 2 \\
\hline $\begin{array}{l}\text { Türkçe, Türk Dili ve Edebiyatı, İngilizce, Sınıf } \\
\text { Öğretmeni, Din Kültürü ve Ahlak Bilgisi, İmam Hatip } \\
\text { Meslek Dersleri (iHL), Sosyal Bilgiler Öğretmeni }\end{array}$ & İngilizce & 120 \\
\hline $\begin{array}{l}\text { Türkçe, Türk Dili ve Edebiyatı, İngilizce, Sınıf } \\
\text { Öğretmeni }\end{array}$ & $\begin{array}{l}\text { İngilizce/ } \\
\text { İtalyanca }\end{array}$ & 2 \\
\hline TOPLAM & & 345 \\
\hline
\end{tabular}


Millî Eğitim Bakanlığının Yurt Dışına Türkçe ve Türk Kültürü Dersi Öğretmeni Görevlendirme Politikasının Yıllara Göre Değerlendirilmesi

2014 yılında Türkçe ve Türk Kültürü dersi vermek üzere Türkçe, Türk dili ve edebiyatı, İngilizce, Fransızca, Almanca, sınıf, din kültürü ve ahlak bilgisi, sosyal bilgiler, okul öncesi öğretmeni, rehber öğretmen branşlarında atamalar yapılmıştır. İmam hatip meslek dersleri öğretmeni ilk kez listede yer almıştır. Bu yıl için görevlendirilecek toplam öğretmen sayısı 345'tir.

Tablo 7.

2015 Yılı Türkçe ve Türk Kültürü Ders Öğretmeni Olarak Atanmaya Esas Olan Alanlar ve Öğretmen Sayıları

\begin{tabular}{llc}
\hline \multicolumn{1}{c}{ Atanmasına Esas Olan Alan } & Yabancı Dili & Seçilecek Öğretmen Sayısı \\
\hline $\begin{array}{l}\text { Türkçe, Türk Dili ve Edebiyatı, Almanca, } \\
\text { Sını Öğretmeni, Sosyal Bilgiler, Din Kültürü } \\
\text { ve Ahlak Bilgisi }\end{array}$ & Almanca & 150 \\
Okul Öncesi & Almanca/ & 16 \\
& $\begin{array}{l}\text { İngilizce } \\
\text { Rehberlik }\end{array}$ & $\begin{array}{l}\text { Almanca/ } \\
\text { İngilizce }\end{array}$ \\
Beden Eğitimi, Sınıf Öğretmeni (Resmi & Almanca/ & 12 \\
Kurumlardan alınmış Halk Oyunları Usta & İngilizce & 20 \\
Öğreticilik Belgesi Olanlar), Müzik & & \\
Türkçe, Türk Dili ve Edebiyatı, Fransızca, Sınıf & Fransızca & \\
Öğretmeni, Sosyal Bilgiler, Din Kültürü ve & & 60 \\
Ahlak Bilgisi & & \\
Rehberlik & Fransızca/ & 4 \\
Ingilizce & İngilizce & 100 \\
Sını Öğretmeni & İngilizce & 25 \\
Türkçe, Türk Dili ve Edebiyatı & İngilizce & 25 \\
Din Kültürü ve Ahlak Bilgisi & Ingilizce & 15 \\
Matematik & İngilizce & 2 \\
\hline TOPLAM & İngilizce & 429 \\
\hline
\end{tabular}

2015 yılı Türkçe ve Türk Kültürü dersi öğretmeni olarak 2010-2019 yılları arasında yurt dışına en çok görevlendirmenin yapıldığı yıldır. 2015 yılında seçilecek öğretmen sayısı 429'dur. Türkçe, Türk dili ve edebiyatı, Almanca, Fransızca, İngilizce, sınıf, sosyal bilgiler, din kültürü ve ahlak bilgisi, beden eğitimi, müzik öğretmeni 2015 yılının atanmaya esas alanlarıdır. Matematik öğretmenleri de ilk kez bu yıl listeye dâhil olmuştur.

2016 yılında Gürcistan, Bahreyn, Lübnan, Tunus, Karadağ, Katar, Kuveyt, Türk Cumhuriyetlerine öğretmen ataması gerçekleştirilmiş ancak Türkçe ve Türk Kültürü dersi öğretmeni seçimi/görevlendirmesi yapılmamıştır.

Tablo 8 .

2017 Yılı Türkçe ve Türk Kültürü Ders Öğretmeni Olarak Atanmaya Esas Olan Alanlar ve Öğretmen Sayıları

\begin{tabular}{lcc}
\hline Atamaya Esas Olan Alan & Yabancı Dili & Seçilecek Öğretmen Sayısı \\
\hline İngilizce, Sını Öğretmeni, Türkçe, Türk Dili ve & İngilizce & 55 \\
Edebiyatı, Din Kültürü ve Ahlak bilgisi & \\
Sosyal bilgiler & İngilizce & 2 \\
Muhasebe ve Finansman & İngilizce & 1 \\
\hline TOPLAM & & 58 \\
\hline
\end{tabular}


2017 yılı en az Türkçe ve Türk Kültürü dersi öğretmeni görevlendirmesinin yapıldığı yıldır. 2017'de seçilen öğretmen sayısı 58'dir. İngilizce, sınıf, Türkçe, Türk dili ve edebiyatı, din kültürü ve ahlak bilgisi, sosyal bilgiler, muhasebe ve finansman öğretmeni atanmaya esas alanlar olarak kabul edilmiştir. 2017 yılında atanmaya esas alanların azaldığı görülmektedir. Ayrıca muhasebe ve finansman öğretmeni listeye ilk kez girmiştir.

Tablo 9.

2018 Yılı Türkçe ve Türk Kültürü Ders Öğretmeni Olarak Atanmaya Esas Olan Alanlar ve Öğretmen Sayıları

\begin{tabular}{lcc}
\hline Atamaya Esas Olan Alan & Yabancı Dili & Seçilecek Öğretmen Sayısı \\
\hline $\begin{array}{l}\text { İngilizce, Sını Öğretmeni, Türkçe, Türk Dili ve } \\
\text { Edebiyatı, Sosyal Bilgiler, Din Kültürü ve Ahlak }\end{array}$ & Ingilizce & 58 \\
bilgisi & Ingilizce & 2 \\
Beden Eğitimi ( en az iki yöre için halk & & \\
oyunları öğretici sertifikası olanlar) & Ingilizce & 3 \\
Matematik & İngilizce & 3 \\
Muhasebe ve Finansman & İngilizce & 68 \\
Okul Öncesi & & 3 \\
\hline TOPLAM & & \\
\hline
\end{tabular}

2018 yılında İngilizce, sınıf, Türkçe, Türk dili ve edebiyatı, sosyal bilgiler, din kültürü ve ahlak bilgisi, beden eğitimi, matematik, muhasebe ve finansman, okulöncesi öğretmeni atanmaya esas olan alanlar olarak sıralanmıştır. 2018 yılında seçilen öğretmen sayısı 68'dir.

2019 yılına ait Yurt Dışında Görevlendirilecek Öğretim Üyesi/Öğretim Görevlisi/Okutman Seçme Sınavı Başvuru Kılavuzu'nda Türkçe ve Türk kültürü ders öğretmeni olarak atanmaya esas alanlar ve sayılara ilişkin bilgiye yer verilmemiştir.

2010-2019 yılları arasında Türkçe ve Türk Kültürü dersi öğretmeni olarak atanmaya esas olan alanlar genel olarak değerlendirildiğinde Bakanlı̆ı̆n Türkçe ve Türk Kültürü dersinin içeriğine uygun alanlarda atama yapmadığı görülmektedir. Özellikle Muhasebe ve Finans, Matematik, Beden eğitimi, Müzik, İmam Hatip Meslek Dersleri, Din Kültürü ve Ahlak Bilgisi, Sosyal Bilgiler öğretmenlerinin lisans eğitimleri göz önüne alındığında Türkçe ve Türk Kültürü dersi öğretmeni olarak atamaların uygun olmadığı düşünülmektedir.

\section{Türkçe ve Türk Kültürü Ders Öğretmeni Olarak Görevlendirilecek Öğretmenler İçin Yapılan Sınavlara iliş̧kin Bulgular}

Millî Eğitim Bakanlığı öğretmenlerin seçiminde iki aşamalı bir sınav uygulamaktadır. Bu politikası 2010-2019 yılları arasında değişmemiştir. Başvurusu kabul edilen öğretmenler, öncelikle Mesleki Yeterlik Sınavına girmektedir. Bu sınav, çoktan seçmeli, dört seçenekli 100 sorudan oluşmaktadır. Bu sınavdan Bakanlığın belirlediği baraj puanını geçenler (Önceki yıllarda 70 ve üstü iken 2019 yılında 60 puan ve üzeri puan alan adaylar başarı puanı en yüksekten başlayarak başarı sıralaması yapılmıştır.) ikinci aşamaya yani Temsil Yeteneği Mülakatına geçmektedir. Bu mülakat, Bakanlıklararası Kültür Komisyonunca oluşturulan jüri tarafından yapılmaktadır. Mülakattan Bakanlığın belirlediği baraj puanını geçenler (70 puan) Türkçe ve Türk Kültürü dersi öğretmeni olarak görevlendirilirler. Sınavların içeriğine ilişkin veriler aşağıda sunulmuştur.

Tablo 10.

Türkçe ve Türk Kültürü Ders Öğretmeni Olarak Görevlendirilecek Öğretmenler İçin Yapılan Sınavlar

\begin{tabular}{|c|c|c|c|c|c|c|c|c|c|c|}
\hline \multirow[t]{2}{*}{ Sinavlar } & \multicolumn{10}{|c|}{ Yıllar } \\
\hline & 2010 & 2011 & 2012 & 2013 & 2014 & 2015 & 2016 & 2017 & 2018 & 2019 \\
\hline Mesleki Yeterlik Sınavı & + & + & + & + & + & + & - & + & + & + \\
\hline $\begin{array}{l}\text { Temsil } \\
\text { Mülakatı }\end{array}$ & + & + & + & + & + & + & + & + & + & + \\
\hline
\end{tabular}


Millî Eğitim Bakanlığının Yurt Dışına Türkçe ve Türk Kültürü Dersi Öğretmeni Görevlendirme Politikasının Yıllara Göre Değerlendirilmesi

Tabloya bakıldığında sadece 2016 yılında Mesleki Yeterlilik Sınavı yapılmamış, öğretmenler sadece sözlü sınava girmiştir. Ayrıca daha önce de ifade edildiği gibi 2016 yılında Türkçe ve Türk kültürü dersi öğretmeni görevlendirmesi yapılmamıştır.

Tablo 11.

2010-2019 Yılları Mesleki Yeterlik Sınavı Türkçe Konu Alanı

\begin{tabular}{clll}
\hline Yıllar & $\begin{array}{l}\text { Mesleki Yeterlik Sınavı: } \\
\text { Türkçe Konu Alanı }\end{array}$ & Soru Sayısı & Puan Değeri \\
\hline 2010 & $\begin{array}{l}\text { Türkçe } \\
\text { (Türkçeyi doğru kullanma, dilbilgisi ve anlam bilgisi) }\end{array}$ & 25 & 25 \\
2011 & $\begin{array}{l}\text { Türkçe (Türk Dili ve Edebiyatı, dilbilgisi ve anlam bilgisi, } \\
\text { vb.) }\end{array}$ & 25 & 25 \\
2012 & $\begin{array}{l}\text { Türkçe (Türk Dili Edebiyatı, Türk Edebiyatı Tarihi, Dil } \\
\text { bilgisi, vb) }\end{array}$ & - & 25 \\
2013 & $\begin{array}{l}\text { Türkçe (Türk Dili Edebiyatı, Türk Edebiyatı Tarihi, Dil } \\
\text { bilgisi vb.) }\end{array}$ & - & 25 \\
2014 & $\begin{array}{l}\text { Türkçe (Türk Dili Edebiyatı, Türk Edebiyatı Tarihi, Dil } \\
\text { Bilgisi vb.) }\end{array}$ & - & 25 \\
2015 & $\begin{array}{l}\text { Türkçe (Türk Dili Edebiyatı, Türk Edebiyatı Tarihi, Dil } \\
\text { Bilgisi, anlam bilgisi vb.) }\end{array}$ & - & 25 \\
2016 & $\begin{array}{l}\text { - } \\
\text { Türkçe (Türk Dili Edebiyatı, Dil Bilgisi, Anlam Bilgisi vb.) } \\
\text { Türkçe (Türk Dili ve Edebiyatı, Dil Bilgisi ve Anlam } \\
\text { Bilgisi vb.) } \\
\text { Türkçe (Türk Dili ve Edebiyatı, Dil Bilgisi ve Anlam } \\
\text { Bilgisi vb.) }\end{array}$ & - & - \\
2019 & - & 25 \\
\hline
\end{tabular}

Tablo 11'e göre Bakanlık her yıl öğretmenlerin Türkçe yeterliliklerini ölçmektedir. Türkçe sorularının 2010 yılında "Türkçeyi doğru kullanma, dilbilgisi ve anlam bilgisi" konularını, 2011-2014 yıllarında "Türk Dili Edebiyatı, Türk Edebiyatı Tarihi, Dil bilgisi" konularını, 2015'te " Türk Dili Edebiyatı, Türk Edebiyatı Tarihi, Dil Bilgisi, anlam bilgisi" konularını, son üç yıldır "Türk Dili ve Edebiyatı, Dil Bilgisi, Anlam Bilgisi" konularını içerdiği görülmektedir.

Tablo 12.

2010-2019 Yılları Mesleki Yeterlik Sınavı Sosyal Bilimler Konu Alanı

\begin{tabular}{|c|c|c|c|}
\hline Yillar & $\begin{array}{l}\text { Mesleki Yeterlik Sınavı: } \\
\text { Sosyal Bilimler Konu Alanı }\end{array}$ & Soru Sayısı & Puan Değeri \\
\hline 2010 & $\begin{array}{l}\text { Sosyal Bilimler (Atatürk Illkeleri ve T.C. İnkılâp Tarihi, Türk } \\
\text { Tarihi, Türk Kültür ve Medeniyeti, Türkiye Coğrafyası, } \\
\text { Vatandaşlık Bilgileri) }\end{array}$ & 25 & 25 \\
\hline 2011 & $\begin{array}{l}\text { Sosyal Bilimler (Atatürk Illkeleri ve T.C. İnkılâp Tarihi, Türk } \\
\text { Tarihi, Türk Kültür ve Medeniyeti, Türkiye Coğrafyası, } \\
\text { Vatandaşlık Bilgileri, vb.) }\end{array}$ & 25 & 25 \\
\hline 2012 & $\begin{array}{l}\text { Sosyal Bilimler (Atatürk ilkeleri ve T.C. İnkılâp Tarihi, Türk } \\
\text { Tarihi, Türk Kültür ve Medeniyeti, Türkiye Coğrafyası, } \\
\text { Vatandaşlık Bilgileri, vb.) }\end{array}$ & - & 25 \\
\hline 2013 & $\begin{array}{l}\text { Sosyal Bilimler (Atatürk illkeleri ve T.C. İnkılâp Tarihi, Türk } \\
\text { Tarihi, Türk Kültür ve Medeniyeti, Türkiye Coğrafyası, } \\
\text { Vatandaşlık Bilgileri, vb.) }\end{array}$ & - & 25 \\
\hline
\end{tabular}


Tablo 12.

2010-2019 Yılları Mesleki Yeterlik Sınavı Sosyal Bilimler Konu Alanı (Devamı)

\begin{tabular}{|c|c|c|c|}
\hline Yıllar & $\begin{array}{l}\text { Mesleki Yeterlik Sınavı: } \\
\text { Sosyal Bilimler Konu Alanı }\end{array}$ & Soru Sayısı & Puan Değeri \\
\hline 2014 & $\begin{array}{l}\text { Sosyal Bilimler (Atatürk İlkeleri ve T.C. İnkılâp Tarihi, Türk } \\
\text { Tarihi, Türk Kültür ve Medeniyeti, Türkiye Coğrafyası, } \\
\text { Vatandaşlık Bilgileri, vb.) }\end{array}$ & - & 25 \\
\hline 2015 & $\begin{array}{l}\text { Sosyal Bilimler (Atatürk illkeleri ve T.C. İnkılâp Tarihi, Türk } \\
\text { Tarihi, Türk Kültür ve Medeniyeti, Türkiye Coğrafyası, } \\
\text { Vatandaşlık Bilgileri vb.) }\end{array}$ & - & 25 \\
\hline 2016 & - & - & - \\
\hline 2017 & $\begin{array}{l}\text { Sosyal Bilimler (Atatürk İlkeleri ve T.C. İnkılâp Tarihi, Türk } \\
\text { Tarihi, Türk Kültür ve Medeniyeti, Türkiye Coğrafyası, } \\
\text { Vatandaşlık Bilgileri vb.) }\end{array}$ & - & 25 \\
\hline 2018 & $\begin{array}{l}\text { T.C. İnkılap Tarihi ve Atatürkçülük, Türk Tarihi, Türk } \\
\text { Kültür ve Medeniyeti, Türkiye Coğrafyası, Vatandaşlık } \\
\text { Bilgileri vb. }\end{array}$ & - & 25 \\
\hline 2019 & $\begin{array}{l}\text { T.C. İnkılap Tarihi ve Atatürkçülük, Türk Tarihi, Türk } \\
\text { Kültür ve Medeniyeti, Türkiye Coğrafyası, Vatandaşlık } \\
\text { Bilgisi vb. }\end{array}$ & - & 25 \\
\hline
\end{tabular}

Tablo 12'de görüleceği üzere Mesleki Yeterlik Sınavında sosyal bilimler başlığı altında her yıl aynı içerikle hazırlanan bir sınav politikası izlenmiştir.

Tablo 13.

2010-2019 Yılları Mesleki Yeterlik Sınavı Mesleki Bilgi Konu Alanı

\begin{tabular}{|c|c|c|c|}
\hline Yıllar & $\begin{array}{l}\text { Mesleki Yeterlik Sınavı: } \\
\text { Mesleki Bilgi Konu Alanı }\end{array}$ & Soru Sayısı & Puan Değeri \\
\hline 2010 & Mesleki Bilgi (Öğretmenlik Meslek Bilgisi) & 25 & 25 \\
\hline 2011 & Mesleki Bilgi (Öğretmenlik Meslek Bilgisi) & 25 & 25 \\
\hline 2012 & Mesleki Bilgi (Öğretmenlik Meslek Bilgisi) & - & 25 \\
\hline 2013 & Mesleki Bilgi (Öğretmenlik Meslek Bilgisi) & - & 25 \\
\hline 2014 & Mesleki Bilgi (Öğretmenlik Meslek Bilgisi) & - & 25 \\
\hline 2015 & $\begin{array}{l}\text { Mesleki Bilgi (Öğretmenlik Meslek Bilgisi, Millî Eğitim } \\
\text { Mevzuatı) }\end{array}$ & - & 25 \\
\hline 2016 & - & - & - \\
\hline 2017 & $\begin{array}{l}\text { Mesleki Bilgi (Öğretmenlik Meslek Bilgisi, Millî Eğitim } \\
\text { Mevzuatı) }\end{array}$ & - & 25 \\
\hline 2018 & $\begin{array}{l}\text { Mesleki Bilgi (Öğretmenlik Meslek Bilgisi, Millî Eğitim } \\
\text { Mevzuatı) }\end{array}$ & - & 25 \\
\hline 2019 & $\begin{array}{l}\text { Öğretim Yöntem ve Teknikleri, } \\
\text { Mevzuat* }\end{array}$ & - & 25 \\
\hline
\end{tabular}

"Mesleki Yeterlik Sınavı"nda mesleki bilgi konu alanında 2015 yılına kadar adayların öğretmenlik meslek bilgisi ölçülürken 2015 yılından itibaren içeriğe Millî Eğitim Mevzuatı'nın da eklendiği görülmektedir. 2019 yılında mevzuatın içeriğine ilişkin sınırlılık da getirilmiştir. 
Millî Eğitim Bakanlığının Yurt Dışına Türkçe ve Türk Kültürü Dersi Öğretmeni Görevlendirme Politikasının Yıllara Göre Değerlendirilmesi

Tablo 14.

2010-2019 Yılları Mesleki Yeterlik Sınavı Genel Kültür Konu Alanı

\begin{tabular}{|c|c|c|c|}
\hline Yıllar & $\begin{array}{l}\text { Mesleki Yeterlik Sınavı: } \\
\text { Genel Kültür Konu Alanı }\end{array}$ & Soru Sayısı & Puan Değeri \\
\hline 2010 & $\begin{array}{l}\text { Genel Kültür (Aktüalite, Uluslararası Kuruluşlar, } \\
\text { Ekonomi, Türk Edebiyatı, Millî Eğitim Mevzuatı) }\end{array}$ & 25 & 25 \\
\hline 2011 & $\begin{array}{l}\text { Genel Kültür (Güncel Bilgiler, Uluslararası Kuruluşlar, } \\
\text { Ekonomi, Millî Eğitim Mevzuatı, vb.) }\end{array}$ & 25 & 25 \\
\hline 2012 & $\begin{array}{l}\text { Genel Kültür (Güncel Bilgiler, Uluslararası Kuruluşlar, } \\
\text { Ekonomi, Millî Eğitim Mevzuatı, vb.) }\end{array}$ & - & 25 \\
\hline 2013 & $\begin{array}{l}\text { Genel Kültür (Güncel Bilgiler, Uluslararası Kuruluşlar, } \\
\text { Ekonomi, Millî Eğitim Mevzuatı,vb.) }\end{array}$ & - & 25 \\
\hline 2014 & $\begin{array}{l}\text { Genel Kültür (Güncel Bilgiler, Uluslararası Kuruluşlar, } \\
\text { Ekonomi, Millî Eğitim Mevzuatı,vb.) }\end{array}$ & - & 25 \\
\hline 2015 & $\begin{array}{l}\text { Genel Kültür (Güncel Bilgiler, Uluslararası Kuruluşlar, } \\
\text { Ekonomi vb.) }\end{array}$ & - & 25 \\
\hline 2016 & - & - & - \\
\hline 2017 & $\begin{array}{l}\text { Genel Kültür (Güncel Bilgiler, Uluslararası Kuruluşlar, } \\
\text { Ekonomi vb.) }\end{array}$ & - & 25 \\
\hline 2018 & $\begin{array}{l}\text { Genel Kültür (Güncel Bilgiler, Uluslararası Kuruluşlar, } \\
\text { Ekonomi vb.) }\end{array}$ & - & 25 \\
\hline 2019 & $\begin{array}{l}\text { Genel Kültür (Güncel Bilgiler, Uluslararası Kuruluşlar, } \\
\text { Ekonomi vb.) }\end{array}$ & - & 25 \\
\hline
\end{tabular}

"Mesleki Yeterlik Sınavı"nda genel kültür konu alanında 2010-2015 yılları arasında "Güncel Bilgiler, Uluslararası Kuruluşlar, Ekonomi, Millî Eğitim Mevzuatı" başıklarını içeren sınav hazırlanırken 2015 yılından itibaren genel kültür konu alanı içeriğinden "Millî Eğitim Mevzuatı" çıkarılmıştır. Millî Eğitim Mevzuatı konusu 2015 yılından itibaren mesleki bilgi içeriğine dâhil edilmiştir. 2012 ve sonrası Kılavuzlarda soru sayısı belirtilmemiş olsa da sınav toplam puanı ve sınav alanlarının puan değerleri dikkate alındığında her bölümde 25 soru dağılımının olduğu anlaşılmaktadır.

Tablo 15.

2010-2019 Yılları Temsil Yeteneği Mülakatı Türkçeyi Kullanma Becerisi Konu Alanı

\begin{tabular}{lll}
\hline Yıllar & $\begin{array}{l}\text { Temsil Yeteneği Mülakatı: } \\
\text { Türkçeyi Kullanma Becerisi }\end{array}$ & Puan Değeri \\
\hline 2010 & $\begin{array}{l}\text { Türkçeyi Doğru Kullanma Becerisi } \\
\text { Türkçe }\end{array}$ & 25 \\
& a) Sözlü Iffade edebilme yeteneği & 15 \\
& b) Yazııı Ifade edebilme yeteneği (Kompozisyon) & 20 \\
2012 & Türkçe (Türkçeyi doğru kullanma, Türk Dili Edebiyatı, Türk & 25 \\
& Edebiyatı Tarihi, Dil bilgisi ve anlam bilgisi vb.) & \\
2013 & Türkçeyi Doğru Kullanma Becerisi & 25 \\
2014 & Türkçeyi Doğru Kullanma Becerisi & - \\
2015 & Türkçeyi Doğru Kullanma Becerisi & 25 \\
2016 & Türkçeyi Doğru Kullanma Becerisi & 25 \\
2017 & Türkçeyi Doğru Kullanma Becerisi & 25 \\
2018 & Türkçe ( Türk Dili ve Edebiyatı, Dil Bilgisi ve Anlam Bilgisi vb.) & 25 \\
2019 & Türkçe Alanında Yaptığı Bilimsel Çalışmalar & 30 \\
\hline
\end{tabular}

Temsil Yeteneği Mülakatında 2010-2017 yıllarında adayların Türkçeyi kullanma becerileri ölçülürken 2018 yılında adayların becerileri değil bilgi düzeyleri puanlamaya esas olmuştur. Ayrıca 2011 
yılı dışında diğer yıllarda adayların yazma becerilerinin dikkate alınmadığı görülmektedir. Bununla birlikte 2019 yılında adayların Türkçeyi kullanma becerileri değil Türkçe alanında yaptıkları bilimsel çalışmalar dikkate alınmıştır. Adayların bu alandaki çalışmaları son on yılın en yüksek puan değerine karşılık gelmektedir.

Tablo 16.

2010-2019 Yılları Temsil Yeteneği Mülakatı Milli Şuur, Atatürk IIlkeleri ve T.C. Inkılap Tarihi Konu Alanı

\begin{tabular}{lll}
\hline Yıllar & Temsil Yeteneği Mülakatı: & Puan Değeri \\
& Millî Şuur, Atatürk İlkeleri ve T. C. İnkılap Tarihi & \\
\hline 2010 & Millî Şuur, Atatürk IIlkeleri ve T. C. İnılap Tarihi & 25 \\
2011 & Millî Şuur, Atatürk İlkeleri ve T.C. İnıılap Tarihi, vb. & 20 \\
2012 & Millî Şuur, Atatürk IIlkeleri ve T.C. Inkılap Tarihi, vb. & 25 \\
2013 & Millî Şuur, Atatürk IIlkeleri ve T. C. İnılap Tarihi & 25 \\
2014 & Millî Şuur, Atatürk İlkeleri ve T. C. İnkılap Tarihi & - \\
2015 & Millî Şuur, Atatürk IIlkeleri ve T. C. İnılap Tarihi & 25 \\
2016 & Millî Şuur, Atatürk İlkeleri ve T. C. İnılap Tarihi & 25 \\
2017 & Millî Şuur, Atatürk IIlkeleri ve T. C. İnkılap Tarihi & 25 \\
2018 & T.C. İnkılap Tarihi ve Atatürkçülük, Türk Tarihi, Türk Kültür ve & 25 \\
& Medeniyeti, Türkiye Coğrafyası, Vatandaşlık Bilgileri vb. & \\
2019 & T.C. İnkılap Tarihi ve Atatürkçülük & 25 \\
\hline
\end{tabular}

Temsil Yeteneği Mülakatında 2018 yılı hariç her yıl adayların "Millî Şuur, Atatürk illkeleri ve T. C. İnkılâp Tarihi" bilgileri değerlendirilirken 2018 yılında "Türk Tarihi, Türk Kültür ve Medeniyeti, Türkiye Coğrafyası, Vatandaşlık Bilgileri" de değerlendirilmiştir. 2019 yılında millî şuur değerlendirmeden çıkarılmış, "Atatürk İlkeleri ve T. C. İnkılâp Tarihi" ifadesi de değişikliğe uğramış, "T.C. İnkılap Tarihi ve Atatürkçülük" şeklinde bir değerlendirme kriteri getirilmiştir.

Tablo 17.

2010-2019 Yılları Temsil Yeteneği Mülakatı Genel Kültür Konu Alanı

\begin{tabular}{lll}
\hline Yıllar & $\begin{array}{l}\text { Temsil Yeteneği Mülakatı: } \\
\text { Genel Kültür }\end{array}$ & Puan Değeri \\
\hline 2010 & Genel Kültür & 25 \\
2011 & $\begin{array}{l}\text { Genel Kültür(Güncel Bilgiler, Uluslararası Kuruluşlar, Ekonomi, Türk } \\
\text { Edebiyatı, Millî Eğitim Mevzuatı, Eğitim Bilimleri, Yurtdışı Görev }\end{array}$ & 20 \\
& Bilgisi, Farklı Ülke Kültürleri, vb.) & \\
2012 & Genel Kültür (Güncel Bilgiler, Uluslararası Kuruluşlar, Ekonomi, Türk & 25 \\
& Edebiyatı, Millî Eğitim Mevzuatı, Eğitim Bilimleri, Yurtdışı Görev & \\
& Bilgisi, Farklı Ülke Kültürleri, vb.) & \\
2013 & Genel Kültür & 25 \\
2014 & Genel Kültür & - \\
2015 & Genel Kültür & 25 \\
2016 & Genel Kültür, Mevzuat & 25 \\
2017 & Genel Kültür, Mevzuat & 25 \\
2018 & Genel Kültür, Mevzuat & 25 \\
2019 & Genel Kültür & 25
\end{tabular}

Temsil Yeteneği Mülakatında 2011 ve 2012 yılları dışında genel kültür alanında içerik belirtilmemiştir. Ancak diğer alanlar da olduğu gibi genel kültür konu alanı da Bakanlığın adaylarda her yıl değerlendirmeye tabi tuttuğu bir alan olarak karşımıza çıkmaktadır. 2019 yılında mevzuat bilgisi değerlendirme kriterlerinden çıkarılmıştır. 
Millî Eğitim Bakanlığının Yurt Dışına Türkçe ve Türk Kültürü Dersi Öğretmeni Görevlendirme Politikasının Yıllara Göre Değerlendirilmesi

Tablo 18.

2010-2019 Yılları Temsil Yeteneği Mülakatı Genel Görünüm, Tutum ve Davranış Konu Alanı

\begin{tabular}{lll}
\hline Yıllar & Temsil Yeteneği Mülakatı: & Puan Değeri \\
\hline 2010 & Genel Görünüm, Tutum ve Davranış & 25 \\
2011 & Genel Görünüm, Tutum ve Davranış & 15 \\
2012 & Genel Görünüm, Tutum ve Davranış & 25 \\
2013 & Genel Görünüm, Tutum ve Davranış & 25 \\
2014 & Genel Görünüm, Tutum ve Davranış & - \\
2015 & Genel Görünüm, Tutum ve Davranış & 25 \\
2016 & Genel Görünüm, Tutum ve Davranış & 25 \\
2017 & Genel Görünüm, Tutum ve Davranış & 25 \\
2018 & Liyakat ve Temsil Kabiliyeti & 25 \\
2019 & Liyakati, Temsil Kabiliyeti, Tutum ve Davranışlarının Göreve & 20 \\
& Uygunluğu & \\
\hline
\end{tabular}

Temsil Yeteneği Mülakatının gözleme dayalı değerlendirmeyi de içerdiği görülmektedir. 20102017 yılları arasında yapılan Temsil Yeteneği Mülakatında Komisyonun adayların genel görünümleri, tutumları ve davranışları üzerinden bir değerlendirme yaptığı anlaşılmaktadır. 2018 yılında ise liyakat ve temsil kabiliyeti açısından bir değerlendirmenin yapıldığı görülmektedir. 2018 yılında ilk kez kullanılan liyakat ve temsil kabiliyeti ifadesi 2019 yılında da karşımıza çıkmaktadır. 2019 yılına ek olarak adayın tutum ve davranışlarının göreve uyumlu olup olmadığı da değerlendirme kriteridir.

\section{Türkçe ve Türk Kültürü Ders Öğretmeni Olarak Görevlendirilecek Öğretmenler İçin Yapılan Uyum Seminerine ilişkin Bulgular}

"Mesleki Yeterlilik Sınavı ve Temsil Yeteneği Sınavında başarılı olup yurt dışında görevlendirilmeye hak kazanan öğretmenlerden ihtiyaç duyulan alanlar göz önünde bulundurularak, başarı sırasına göre bir kısmı veya tamamı Millî Eğitim Bakanlığınca resen belirlenerek yurt dışı göreve uyum seminerine alınmaktadır." (Yurt Dışında Görevlendirilecek Öğretmenlerin Mesleki Yeterlilik Sınavı Ve Temsil Yeteneği Mülakatı Başvuru Kılavuzu, 2018) Bu politikası da Millî Eğitim Bakanlığııın 2010-2018 yılları arasında değişmemiştir. Uyum seminerlerine katılım zorunlu kılınmıştır. Acil öğretmen ihtiyacının olduğu durumlarda ilgili öğretmenler uyum seminerine alınmadan yurt dışında görevlendirilebilmektedir. Seminerler 15 gün sürmektedir.

Tablo 19.

2010-2019 Yılları Arası Türkçe ve Türk Kültürü Dersi Öğretmeni Olarak Görevlendirilecek Öğretmenler için Yapılan Uyum Seminerleri

\begin{tabular}{llllllllllll}
\hline & \multicolumn{10}{c}{ Yillar } \\
& 2010 & 2011 & 2012 & 2013 & 2014 & 2015 & 2016 & 2017 & 2018 & 2019 \\
\hline $\begin{array}{l}\text { Uyum } \\
\text { Semineri }\end{array}$ & + & + & + & + & + & + & + & + & + & - \\
\hline
\end{tabular}

2019 yılı hariç bütün kılavuzlarda öğretmenlerin uyum seminerine alınacağı, bu seminerlere davet edilenlerin katılımlarının zorunlu olduğu vs. bilgiler yer almaktadır. Kılavuzda (2019) "Acil bir intiyacın oluşması durumunda, Temsil Yeteneği Sınavında başarılı olup Komisyon tarafından uygun görülen Öğretim Üyesi/Öğretim Görevlisi/Okutmanlar uyum seminerine alınmadan da yurt dışında görevlendirilebilecektir." ibaresinin varlığı bir seminerin olduğunu göstermektedir. Ancak seminerin içeriği ve niteliğine ilişkin bir fikir elde edilememektedir.

Tartışma ve Sonuç

Millî Eğitim Bakanlığının yurt dışına Türkçe ve Türk Kültürü dersi öğretmeni görevlendirme politikasının yıllara göre değerlendirmeyi amaçlayan çalışmada şu sonuçlara ulaşımıştır: 
Millî Eğitim Bakanlığı, 2010-2019 yılları arasında Türkçe ve Türk Kültürü dersi öğretmeni olarak görevlendirilecekler için başvuru/görevlendirme şartlarında sınırlayıcı, eleyici bir politika izlememektedir.

Millî Eğitim Bakanlığı 2010-2019 yılları arasında Türkçe ve Türk Kültürü dersi öğretmeni olarak görevlendirilecek öğretmelerin branşlarında dersin içeriğine uygun görevlendirme yapmamaktadır. Bakanlık Türkçe ve Türk kültürü dersleri için İngilizce, Almanca, Fransızca, Sınıf, Türkçe, Türk Dili ve Edebiyatı, Sosyal Bilgiler, Din Kültürü ve Ahlak Bilgisi, Beden Eğitimi, Matematik, Muhasebe ve Finansman, Okulöncesi, İmam Hatip Meslek Dersleri, Özel Eğitim, Tarih öğretmenlerini görevlendirebilmektedir. Atamaya esas olan branşlara bakıldığında Millî Eğitim Bakanlığı, 2010-2019 yılları arasında Türkçe ve Türk Kültürü dersi öğretmeni olarak görevlendirilecekler için alana uygun branşta atama politikası belirlenmediği görülmüştür.

Millî Eğitim Bakanlığı, 2010-2019 yılları arasında 2016 yılı hariç her yıl ortalama 200 öğretmen görevlendirmektedir. Her yıl görevlendirmenin yapılıyor olması Bakanlığın yurt dışındaki Türkiye Cumhuriyeti vatandaşlarının Türkçe ve Türk kültürü ile bağlarını devam ettirmeye yönelik bir politika izlediğini göstermektedir.

Millî Eğitim Bakanlığı 2010-2019 yılları arasında Türkçe ve Türk Kültürü dersi öğretmeni olarak görevlendirilecek öğretmenlerin seçimini iki aşamalı bir şekilde Mesleki Yeterlik Sınavı (test) ve Temsil Yeteneği Mülakatı (sözlü) sınavları ile yapmaktadır. Bakanlık Türkçe ve Türk Kültürü dersi öğretmeni görevlendirmesinde sınav aracılığı ile elemeye dayalı bir seçme ve atama politikası izlemektedir. Yazılı ve sözlü sınavlarda alana yönelik değerlendirme kriterlerinin olmadığı (iki dillilik, Türkçe ve Türk kültürü dersi öğretim programları ve kitapları, vs.) tespit edilmiştir.

Türkçe ve Türk kültürü derslerine yönelik öğretmen yetiştirme amaçlı herhangi bir lisans programı olmadığından bu alana yönelik öğretmen yetişmemektedir, dolayısıyla Bakanlık Türkçe ve Türk Kültürü dersleri için branş dışı atamalar yapmaktadır. Yurt dışında görevlendirilmeye hak kazanan öğretmenler Millî Eğitim Bakanlığınca resen belirlenerek yurt dışı göreve uyum seminerine alınmaktadır. Bakanlığın bu politikası 2010-2019 yılları arasında değişmemiştir. Uyum seminerlerinin niteliği / içeriği hakkında kılavuzlarda bilgilendirmenin olmaması sebebiyle seminerlerin ihtiyaca ne düzeyde cevap verdiği tespit edilememiştir.

Türkçe ve Türk kültürü dersi öğretmenleri ile ilgili literatür taramasında Bakanlığın öğretmen seçme ve atama politikalarına ilişkin ya da öğretmen seçme ve atama sürecine ilişkin bir çalışmaya rastlanmamıştır. Çalışmanın -bu yönüyle- alandaki bir eksikliği giderecek olması sebebiyle önemli olduğu düşünülmektedir. Ayrıca literatür taramasında Türkçe ve Türk kültürü dersi öğretmenleri ile ilgili yapılan çalışmaların süreci değil sonucu değerlendirdiği görülmüştür. Çalışmalarda sıklıkla öğretmenlerin Türkçe ve Türk kültürü derslerine ve ders kitaplarına yönelik görüşlerinin tespit edildiği bu çalışmaları takiben öğretmenlerin öğrencilerin Türkçeyi öğrenme durumlarına ilişkin görüşlerine, mesleki hazırbulunuşluklarına ve kaygılarına, görevlendirmeyi tercih etme nedenlerine değinen çalışmaların varlı̆ıından söz edilebilir (Arıci ve Kırkkılıç, 2017; Belet, 2009; Yıldız ve Çakır, 2016; Çelik, ve Gülcü, 2016; Ekmekçi, 2012; İnce, 2011; Yağımlı, 2015; Şen ve Burgul Adıgüzel, 2018; Burgul Adıgüzel ve Şen, 2018 ).

Kalkınma için Uluslararası İşbirliği Altyapısının Geliştirilmesi Programı (KAGEP) kapsamında Güzel, Baş, Karadağ, Esgin ve Demir (2017) tarafından hazırlanan Türkçe/Türk Kültürü Dersi Mevcut Durum Analizi adlı çalışmada öğretmen merkezli temel sorunlar:

-Motivasyon kaybı,

- Öğretmenlerin kültür ve sanat faaliyetlerindeki yetersizlikleri,

-Öğretmen sayısındaki yetersizlik,

-Öğretmenlerin çok sayıda okulda derse girmeleri,

-Öğretmenlerin yeterli oryantasyon yapılmadan görevlerine gönderilmeleri,

-Öğretmenlerin derse yönelik alt yapı sorunları taşıması,

-Öğretmenlerin bulunduğu ülkenin dilini bilmemelerinden kaynaklanan sorunlar olarak sıralanmıştır. İlgili çalışmanın "Öğretmenlerin yeterli oryantasyon yapılmadan görevlerine gönderilmeleri, öğretmenlerin derse yönelik alt yapı sorunları taşıması, öğretmenlerin bulunduğu 
ülkenin dilini bilmemeleri" verileri, bu çalışmanın süreçte öğretmen seçimin önemli olduğu sonucunu destekler niteliktedir.

Pilancı (2009) tarafından yapılan çalışmada Avrupa'da yaşayan Türklerin Türkçe becerilerinin gelişmesinde öğretmen yetersizliğinin etkili olduğu sonucuna ulaşılmıştır. Demirbaş (2014) ise Avrupa'da yaşayan Türk çocuklarının eğitim ve kültür alanında yaşadıkları sorunları tespit ettiği çalışmasında öğretmenlerin ders içeriği ile uyumsuz branşlara sahip olmasını önemli bir sorun olarak göstermiştir. Yılmaz (2014) Almanya'da yaşayan Türklerin dil sorunlarının sebeplerine yönelik yaptığı çalışmasında öğretmenlerin iki dillilere dil öğretimi konusunda yeterli donanıma sahip olmamalarının temel sorunlardan bir olduğunu ifade etmiştir. Arı (2015) Fransa'da yaşayan Türk velileriyle yaptığı görüşmelerde velilerin Türkçe ve Türk kültürü derslerini yürütmek üzere nitelikli öğretmenlerin görevlendirilmesini talep ettiklerini bildirmiştir. Yağımlı (2015) ise Türkçe ve Türk kültürü derslerini yürüten öğretmenlerin sorunları arasında dersin öğretim programının niteliklerinin bilmemekten kaynaklı deneme yanılma yoluyla derslerin işlenmesini göstermektedir. Arıci ve Kırkkılıç (2017) tarafından yapılan çalışmada da Türkçe ve Türk kültürü dersi veren öğretmenlerin sorunları tespit edilmeye çalışılmıştır. Alan bilgisi ve alt yapısı olmayan öğretmenlerin dersin verimliliğini olumsuz yönde etkilediği çalışmada ulaşılan sonuçlardandır. Literatürde ortaya çıkan sonuçlar bu çalışmanın: Milî̂ Eğitim Bakanlığı 2010-2019 yılları arasında Türkçe ve Türk Kültürü dersi öğretmeni olarak görevlendirilecek öğretmelerin branşlarında dersin içeriğine uygun görevlendirme yapmadığı; yazılı ve sözlü sınavlarda alana yönelik değerlendirme kriterlerinin olmadığı (iki dillilik, Türkçe ve Türk kültürü dersi öğretim programları ve kitapları, vs.); başvuru şartlarında sınırlayıcı, eleyici bir politika izlemediği sonuçları ile örtüştüğü görülmektedir. Bütün bu veriler değerlendirildiğinde sahada öğretmenlerle ilgili yaşanan sorunlarının temel kaynağının öğretmen seçme ve atama sürecinden kaynaklandığı söylenebilir.

Elde edilen sonuçlar doğrultusunda şu öneriler sunulmaktadır:

1. Yılda ortalama 400 (son 10 yııın verilerine göre) öğretmenin yurt dışına görevlendirmesinin yapıldığı göz önüne alındığında "Türkçe ve Türk Kültürü öğretmeni" ihtiyacının olduğu açıktır. Bu sebeple Türkçe ve Türk kültürü derslerini vermek üzere tarih, müzik, matematik vs. branşlarından öğretmen atamaktansa bu alana yönelik öğretmen yetiştirme (lisans) programının açılması önerilmektedir.

2. Alan uzmanı öğretmenlerin atanmadığı mevcut uygulamada ise en azından Millî Eğitim Bakanlığının Türkçe ve Türk Kültürü derslerini vermek üzere müzik, beden eğitimi, tarih, din kültürü ve ahlak bilgisi, matematik, sosyal bilgiler, muhasebe ve finansman, imam hatip meslek dersleri öğretmenlerini görevlendirmemesi önerilmektedir. Diğer branşlarda yapılacak görevlendirmelerde (İngilizce, Almanca, Fransızca, Sınıf, Türkçe, Türk Dili ve Edebiyatı öğretmenliği) ise öncelik Türkçe ve Sınıf öğretmenlerine verilmelidir. Çünkü Türkçe ve Türk kültürü dersi içeriği ile bu branşlarda öğretmen yetiştirme içerikleri uyumludur [bk. Türkçe ve Türk Kültürü Dersi Öğretim Programı (1-8. Seviye)].

3. Uyum semineri gerekli ama yeterli değildir. Kısa süreli bir seminerden ziyade uzun vadeli eğitim programları düzenlenmelidir. Yabancı dil olarak Türkçe öğretimi sertifika programları gibi Yurt Dışındaki Türk Çocuklarına Türkçe Öğretimi Sertifika Programları MEB iş birliği ile üniversiteler bünyesinde hazırlanmalıdır.

4. Mesleki yeterlilik sınavının içeriğine yurt dışındaki Türk varlığı/iki dillilik (özellikleri, türleri, iki dilli eğitim modelleri) / yurt dışındaki Türk çocuklarına Türkçe öğretim programları konu başlıklarını eklenmesi gereklidir. Sınav içeriğinde yukarıdaki konu başlıklarına yönelik soruların olmaması ölçme değerlendirme açısından bir çelişkiyi ortaya çıkarmaktadır. Aynı durum temsil yeteneği sınavı için de geçerlidir.

\section{Kaynaklar}

Arı, T. G. (2015). iki dilli Türk çocuklarının ve velilerin ana dili Türkçeyi öğrenme tutumları (Aisne bölgesiFransa örneği). Yayınlanmamış Yüksek Lisans Tezi. Gazi Üniversitesi Eğitim Bilimleri Enstitüsü. 
Arıci, B. ve Kırkkılıç H. A. (2017). Yurt dışında görev yapan Türkçe ve Türk kültürü öğretmenlerinin Türkçe ve Türk kültürü derslerine ilişkin görüşleri. Akademik Sosyal Sosyal Araştırmalar Dergisi, 5(41), 480-500.

Burgul Adıgüzel, F. ve Şen, Ü. (2018). Türkçe ve Türk kültürü dersi öğretmenlerinin yurt dışı görevlerine ilişkin kaygı ve hazırbulunuşluk durumları. Trakya Eğitim Dergisi, 8 (4), 822-839.

Cumhurbaşkanlığı İdari İşler Başkanlığı Hukuk ve Mevzuat Genel Müdürlüğü. (2003). Resmî gazete. S. 25157.

Cumhurbaşkanlığı İdari İşler Başkanlığı Hukuk ve Mevzuat Genel Müdürlüğü. (2011). Resmî gazete. S. 28054.

Çelik, Y. ve Gülcü, í. (2016). Yurt dışında kullanılan Türkçe ve Türk kültürü ders kitaplarının öğretmen görüşleri açısından değerlendirilmesi. Bartın Üniversitesi Eğitim Fakültesi Dergisi, 5(2), 287296.

Demirbaş, H. (2014). Eğitim-kültür açısından Avrupa'daki Türk çocukları - sorunlar ve çözümler. (1.Baskı), Ankara: Nobel Akademik Yayıncılık.

Ekmekçi, V. (2012). Belçika'da Türkçe dersinin problemleri hakkında öğretmen görüşleri. Gazi Üniversitesi Türkçe Araştırmaları Akademik Öğrenci Dergisi, 2, 1-13.

İnce, B. (2011). Yurt dışında görev yapan Türkçe öğretmenlerinin içinde bulundukları çalışma şartlarına yönelik memnuniyet düzeyleri. Uluslararası Türkçenin Eğitimi- Öğretimi Kurultayı, Ankara: Pegem A.

Millî Eğitim Bakanlığı Avrupa Birliği ve Dış ilişsiler Genel Müdürlüğü (2012). Yurt dışında görevlendirilecek öğretmenlerin mesleki yeterlik sınavı ve temsil yeteneği mülakatı kılavuzu. Ankara: MEB.

Millî Eğitim Bakanlığı Avrupa Birliği ve Dış iliş̧iler Genel Müdürlüğü (2013). Yurt dışında görevlendirilecek öğretmenlerin mesleki yeterlilik sınavı ile temsil yeteneği mülakatı kılavuzu. Ankara: MEB.

Millî Eğitim Bakanlığı Avrupa Birliği ve Dış iliş̧iler Genel Müdürlüğü (2014). Yurt dışında görevlendirilecek öğretmenlerin mesleki yeterlilik sınavı ve temsil yeteneği mülakatı kılavuzu. Ankara: MEB.

Milî̂ Eğitim Bakanlığı Avrupa Birliği ve Dış iliş̧iler Genel Müdürlüğü (2015). Yurt dışında görevlendirilecek öğretmenlerin mesleki yeterlilik sınavı ve temsil yeteneği mülakatı başvuru kılavuzu. Ankara: MEB.

Milî̂ Eğitim Bakanlığı Dış Illişkiler Genel Müdürlüğü (2019). Yurt dışında görevlendirilecek öğretim üyesi/öğretim görevlisi/okutman seçme sınavı başvuru kılavuzu. Ankara: MEB.

Millî Eğitim Bakanlığı Eğitim Teknolojileri Genel Müdürlüğü Dış İlişkiler Genel Müdürlüğü (2010). Yurt dışında görevlendirilecek öğretmenlerin mesleki yeterlilik sınavı ile temsil yeteneği mülakat kılavuzu. Ankara: MEB.

Millî Eğitim Bakanlığı Eğitim Teknolojileri Genel Müdürlüğü Dış İlişkiler Genel Müdürlüğü (2011). Yurt dışında görevlendirilecek öğretmenlerin mesleki yeterlilik sınavı ile temsil yeteneği mülakat kılavuzu. Ankara: MEB.

Millî Eğitim Bakanlığı Yüksek Öğretim ve Yurt Dışı Eğitim Genel Müdürlüğü (2016). Yurt dışında görevlendirilecek öğretmenleri seçme sınavı ve görevlendirme kılavuzu. Ankara: MEB.

Millî Eğitim Bakanlığı Yüksek Öğretim ve Yurt Dışı Eğitim Genel Müdürlüğü (2017). Yurt dışında görevlendirilecek öğretmenlerin mesleki yeterlilik sınavı ve temsil yeteneği mülakatı başvuru kılavuzu. Ankara: MEB.

Millî Eğitim Bakanlığı Yüksek Öğretim ve Yurt Dışı Eğitim Genel Müdürlüğü Avrupa Birliği ve Dış ilişkiler Genel Müdürlüğü (2018). Yurt dışında görevlendirilecek öğretmenlerin mesleki yeterlilik sınavı ve temsil yeteneği mülakatı başvuru kılavuzu. Ankara: MEB.

Millî Eğitim Bakanlığı. (2017). Kalkınma için uluslararası işbirliği altyapısının geliştirilmesi programı (KAGEP). Türkçe/Türk kültürü dersi mevcut durum analizi. Ankara: MEB.

Şen, Ü. ve Burgul Adıgüzel, F. (2018). Türkçe ve Türk kültürü dersi öğretmenlerinin yurt dışı görevini tercih etme nedenleri ve görevlerine ilişkin beklentileri. Aydın TÖMER Dil Dergisi, 3 (1), 67-90. 
Şimşek, H. (2009). Eğitim tarihi araştırmalarında yöntem sorunu. Ankara Üniversitesi Eğitim Bilimleri Fakültesi Dergisi, 42 (1), 33-51.

Yağımlı, A. (2015.) İki dilli öğrencilerin Türkçe eğitimi ve öğretmenlerinin nitelikleri. II. Avrupalı Türkler Anadili Eğitimi Çalıştayı İkidilli ve Çokdilli Eğitim veren Öğretmenlerin Yeterlikleri. Güleç, İ. Ve İnce, B. (Haz.). Sakarya: Sakarya Üniversitesi Yayınları.

Yıldırım, A., ve Şimşek, H. (2008). Sosyal bilimlerde nitel araştırma yöntemleri. Ankara: Seçkin Yayıncılık.

Yıldız, C. ve Çakır, M. (2016). Almanya'daki Türk öğretmenlerin bu ülkede verdikleri Türkçe ve Türk kültürü dersinin uygulanmasına ilişkin görüşleri ve karşılaştıkları sorunlar. Yabancılara Türkçe Öğretimi Üzerine Araştırmalar (içinde) (s.27-37). Sakarya: Sakarya TÖMER.

Yılmaz, M. Y. (2014). İki dillilik olgusu ve Almanya'daki Türklerin iki dilli eğitim sorunu. Turkish Studies, 9(3), 1641-1651.

\section{Introduction}

\section{Extended Abstract}

With the labor migration to abroad, a growing Turkish population has been formed especially in European countries. The Turks, who were in foreign countries for a temporary period in the beginning, have been living permanently in those countries over the years. Turkey has sought to take various measures with different institutions in order to experience the loss of the rights of citizens in the field of education, economy social security in this situation. Among the measures taken, it is remarkable that the Ministry of National Education delegates the teachers abroad to ensure that the children of the citizens who go abroad as workers to live their mother tongues and that they do not break their cultures. The Ministry of National Education has maintained this policy for the first time in 1965 with 17 teachers in Germany until 2019. In recent years an average 400 teachers have been assigned by Ministry. Teachers who will be working abroad need to be meticulous about their responsibilities as well as their choices. The study was formed from this importance. "What kind of policy has the Ministry of National Education pursued in the selection of the teachers to be appointed in the foreign organizations from past to present, does this policy change according to years?" The answers will be searched in these questions.

\section{Method}

The study is descriptive research. The data of the study were obtained by document analysis. The data source of the study consists of the Professional Qualification Exam and Representation Ability Interview Application Guidelines for Teachers to be assigned abroad. The data obtained within the scope of the study were evaluated with descriptive analysis. According to the years, a comparative evaluation was made under the themes of application conditions, areas of appointment and number of teachers, examinations conducted, compliance seminar. The study area is limited to the period between 2010-2019 when the Ministry of National Education was assigned as a teacher in overseas organizations.

\section{Result and Discussion}

1. The Ministry of National Education does not pursue a restrictive, elimination policy in the application / assignment conditions for those who will be appointed as Turkish and Turkish Culture course teachers between 2010-2019.

2. The Ministry of National Education does not assign appropriate assignments to the content of the courses in the branches of the teachers who will be appointed as Turkish and Turkish Culture course teachers between 2010-2019. Ministry can assign English, German, French, Classroom, Turkish, Turkish Language and Literature, Social Studies, Religious Culture and Moral Knowledge, Physical Education, Mathematics, Accounting and Finance, Preschool, Imam Hatip Vocational Courses, Special Education, History teachers for Turkish and Turkish courses. When the branches that are based on the appointment are examined, it has been observed that the Ministry of National Education has not adopted a policy of appointment in the branch appropriate to the field for those who will be assigned as Turkish and Turkish Culture lesson teachers between 2010-2019.

The Ministry of National Education assigns an average of 200 teachers every year between 2010-2019 except for 2016. Each year the appointment is made, the Republic of Turkey citizens abroad 
shows that the ministry followed a policy intended to maintain their ties with the Turkish and Turkish culture.

3. The Ministry of National Education conducts the selection of the teachers who will be appointed as Turkish and Turkish Culture course teachers between 2010-2019 in two stages with Professional Proficiency Exam (test) and Representation Ability Interview (oral) exams. The Ministry follows a policy of selection and appointment based on screening by means of exam in the assignment of Turkish and Turkish Culture course teacher.

4. As there is no undergraduate program for Turkish and Turkish culture teachers, there is no teacher for this field, so the Ministry appoints non-branch appointments for Turkish and Turkish Culture courses (see art. 2). The teachers who are entitled to work abroad are determined by the Ministry of National Education and taken to the seminar for integration to abroad.This policy of the Ministry has not changed between the years 2010-2019. 